\title{
DAMPAK PENERAPAN MODEL PROBLEM BASED LEARNING (PBL) TERHADAP PENGUASAAN KONSEP DAN KERJA ILMIAH SISWA SMP PADA MATERI TEKANAN ZAT CAIR
}

\author{
Ivonita Trihastuti ${ }^{1}$, Hestiningtyas Yuli Pratiwi ${ }^{2}$, Chandra Sundaygara ${ }^{3}$ \\ Pendidikan Fisika, Universitas Kanjuruhan Malang ${ }^{1,2,3}$

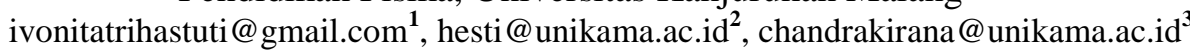

\begin{abstract}
Abstrak. Penelitian ini bertujuan untuk menganalisis: 1) perbedaan penguasaan konsep siswa yang belajar menggunakan model Problem Basel Learning (PBL), 2) perbedaan kerja ilmiah siswa yang belajar dengan model Problem-based Learning (PBL). Metode penelitian yang digunakan adalah quasy experimen (eksperimen semu) dengan desain penelitian menggunakan Postest Only Group Design. Populasi dari penelitian ini adalah seluruh siswa kelas VIII SMPN 10 Malang tahun ajaran 2018/2019. Teknik pengambilan sampel menggunakan teknik Porpusive Sampling. Sampel pada penelitian ini berjumlah 60 siswa dengan rincian 30 siswa sebagai kelas eksperimen dan 30 siswa sebagai kelas kontrol. Teknik pengumpulan data yang digunakan adalah tes penguasaan konsep dan lembar observasi kerja ilmiah. Data yang diperoleh dianalisis dengan menggunakan uji $T$. Hasil penelitian menunjukkan bahwa, 1) terdapat perbedaan penguasaan konsep IPA yang belajar dengan menggunakan Problem Based Learning (PBL) $\mathrm{T}_{\text {hitung }}>\mathrm{T}_{\text {tabel }}(8,793>3,92)$. 2) terdapat perbedaan kerja ilmiah siswa yang belajar dengan model Problem Based Learning (PBL). (PBL) $\mathrm{T}_{\text {hitung }}>\mathrm{T}_{\text {tabel }}(8,465>3,92)$.
\end{abstract}

Kata Kunci: Model Problem Based Learningi (PBL); Penguasaan Konsep; Kerja Ilmiah

\section{PENDAHULUAN}

Pendidikan yang berkualitas tentu tidak akan terlepas dari pengaruh tenaga pendidik yang profesional dalam memberikan pengajaran dan pengalaman kepada siswa. Pendidik yang profesional mampu mewujudkan suasana belajar dan proses pembelajaran agar siswa secara aktif mengembangkan potensi dirinya untuk memiliki kekuatan spiritual, keagamaan, pengendalian diri, kepribadian, akhlak mulia serta keterampilan yang diperlukan dirinya (Nadiya, 2017). Proses pembelajaran yang diharapkan hendaknya mampu melibatkan siswa dalam memperoleh pengetahuan serta menumbuhkan kemampuan bernalar dan kebiasaan berpikir untuk menguasai konsep dan memecahkan masalah yang diberikan oleh guru (Waldrip, Prain, \& Carolan, 2010).

Penguasaan terhadap konsep merupakan hal dasar bagi siswa. Siswa dapat mengaplikasikan konsep, mengaitkan konsep tentang satu dengan konsep yang lain, serta memecahkan masalah yang Ia temukan apabila siswa tersebut sudah memiliki bekal yaitu pengetahuan dasar IPA serta pemahaman dan penguasaan konsep yang memadai. Penguasaan konsep merupakan salah satu bentuk dari hasil belajar yang mengungkap pemahaman siswa terhadap suatu materi yang diajarkan dalam proses belajar. Pencapaian keberhasilan dalam proses pembelajaran tergantung kepada beberapa aspek. Salah satu aspek yang sangat mempengaruhi adalah cara seorang guru dalam melaksanakan pembelajaran. Kecenderungan pembelajaran saat ini masih berpusat pada guru dengan bercerita atau berceramah. Siswa kurang terlihat aktif dalam pembelajaran Ilmu Pengetahuan Alam (1PA). Akibatnya tingkat 
pemahaman siswa terhadap materi pelajaran IPA rendah yang berdampak pada hasil belajar siswa yang rendah (Nadiya, 2017).

Pengetahuan tentang Ilmu Pengetahuan Alam atau fisika, konsep dan gagasan yang terorganisir tentang alam sekitar diperoleh dari serangkaian pengalaman yang dilakukan dengan mengkontruksi fenomena didalamnya (Siswono, Wartono, \& Supriyono, 2017). Fenomena/ fakta sering terjadi dalam proses pembelajaran IPA. Permasalahan yang sering terjadi dalam proses pembelajaran IPA adalah penggunaan model pembelajaran yang belum optimal. Untuk menciptakan suasana pembelajaran kondusif dan menyenangkan perlu adanya pengemasan model pembelajaran yang menarik sehingga siswa tidak lagi merasa terbebani oleh materi ajar yang harus dikuasai. Salah satu model pembelajaran yang dapat digunakan untuk maksud ini adalah model Problem Based Learning (PBL).

Model Problem Based Learning (PBL) merupakan model pembelajaran yang berpusat pada siswa yang menggunakan masalah autentik sebagai landasannya untuk penyelidikan dalam meningkatkan pengetahuannya sendiri, menumbuhkembangkan keterampilan yang lebih tinggi dan meningkatkan kepercayaan diri sendiri (Al-Fikry, Yusrizal, \& Syukri, 2018). Model ini melatih siswa untuk memecahkan masalah dengan pengetahuan yang dimilikinya (Handayani, Agoestanto, \& Masrukan, 2013). Proses tersebut akan membuat terbangunnya pengetahuan baru yang lebih bermakna bagi siswa karena peserta didik mampu menggunakan atau menerapkan materi yang sudah dipelajari dalam kehidupan sehari-hari (Gunantara, Suarjana, \& Riastini, 2014). Model Problem Based Learning (PBL) membuat siswa aktif dalam proses pembelajaran karena pada awal pembelajaran siswa akan dihadapkan pada masalah dunia nyata (real world) dan memecahkan masalah melalui kerja ilmiah (Yoesoef, 2015). Beberapa penelitian telah menunjukkan bahwa model Problem Based Learning (PBL) dapat meningkatkan penguasaan konsep siswa dibandingkan dengan pembelajaran konvensional (Syafi'i, Suryawati, \& Saputra, 2011; Yoesoef, 2015; Handika \& Nur, 2013; Handika \& Nur, 2013).

Model Problem Based Learning (PBL) dalam pembelajaran fisika juga akan mengembangkan kerja ilmiah siswa. Kerja ilmiah merupakan suatu kegiatan yang melatih siswa untuk tidak hanya menerima konsep jadi, melainkan menuntut siswa untuk membuktikan cara memperoleh konsep tersebut (Aji \& Hudha, 2016). Kerja ilmiah akan memudahkan siswa menyelesaikan permasalahan secara logis dan rasional serta dapat meningkatkan kemampuan menganalisis suatu informasi maupun kebenaran suatu pernyataan yang bermanfaat dalam kehidupan sehari-hari. Kerja ilmiah dapat dilakukan melalui pemberian pengalaman dalam bentuk kegiatan mandiri atau kelompok kecil. Salah satu kegiatan yang dapat mendorong agar keterampilan kerja ilmiah ini dapat terlihat yaitu dengan kegiatan praktikum. Kegiatan praktikum dapat dipakai untuk mengembangkan keterampilan-keterampilan proses, membangkitkan minat belajar, serta memberikan bukti-bukti bagi kebenaran teori. Selain itu, kegiatan praktikum juga dapat mengembangkan kemampuan berpikir siswa dalam membangun konsep-konsep materi biologi dan dapat memberikan pengalaman belajar biologi secara nyata kepada siswa serta mengembangkan keterampilan bekerja di laboratorium. Praktikum juga dapat membuat siswa dapat memahami konsep dan memahami hakekat sains sebagai proses dan produk (Wartono dalam Wulandari, dkk, 2014). Melalui kerja ilmiah ini siswa dapat memecahkan masalah dalam proses pembelajaran.

Model Problem Based Learning (PBL) merupakan model pembelajaran yang memberikan kesempatan peserta didik menggali pengalaman autentik sehingga mendorong 
mereka aktif belajar, mengkonstruksi pengetahuan, dan mengintegrasikan konteks belajar disekolah dan kehidupan nyata secara ilmiah (Firmansyah, Kosim, \& Ayub, 2015). PBL merupakan inovasi dalam pembelajaran karena dalam pelaksanaan model pembelajaran ini, kemampuan berpikir siswa betul-betul dioptimalisasikan melalui proses kerja kelompok yang sistematis, sehingga siswa dapat memperdayakan, mengasah, menguji, dan mengembangkan kemampuan berpikirnya secara berkesinambungan (Rusman, 2013). Model Problem Based Learning (PBL) merupakan salah satu model pembelajaran yang menuntut aktivitas mental siswa untuk memahami suatu konsep pembelajaran melalui situasi dan masalah yang disajikan pada awal pembelajaran dengan tujuan untuk melatih siswa menyelesaikan masalah dengan menggunakan pendekatan pemecahan masalah (Kono \& Tangge, 2016).

Penguasaan Konsep merupakan salah satu hasil belajar yang dapat dicapai melaui proses berpikir. Proses berpikir melibatkan proses penalaran yang terdiri dari penalaran induktif dan penalaran deduktif (Anderson \& Krathwohl, 2008). Penguasaan konsep fisika adalah tingkat dimana seorang siswa tidak hanya sekedar mengetahui konsep-konsep fisika saja, melainkan benar-benar memahaminya dengan baik, yang ditunjukkan oleh kemampuannya dalam menyelesaikan berbagai persoalan, baik yang terkait dengan konsep itu sendiri maupun penerapannya dalam situasi baru. Berdasarkan taksonomi bloom penguasaan konsep meliputi domain kognitif CI (mengingat), C2 (memahami), C3 (menerapkan), C4 (menganalisis).

Kerja ilmiah merupakan cara kerja yang dipakai para ilmuwan untuk memecahkan masalah, yaitu dengan menerapkan metode ilmiah. Kerja ilmiah sering dikaitkan dengan kegiatan penyelidikan atau eksperimen. Kerja ilmiah mencerminkan semua aktivitas sains yang melatih dan mengembangkan baik keterampilan sains dan sikap ilmiah. Kegiatan laboratorium dapat dirancang sebagai sarana penelitian ilmiah para ilmuwan dalam menentukan ilmu pengetahuan. Kegiatan laboratorium baik dalam bentuk demonstrasi maupun eksperimen (percobaan), dapat digolongkan menjadi kegiatan laboratorium inkuiri (induktif). Kegiatan laboratorium verifikasi diartikan suatu rangkaian kegiatan observasi atau pengukuran, pengolahan data, dan penarikan kesimpulan yang bertujuan untuk membuktikan konsep yang sudah dibelajarkan. Dalam kegiatan eksperimen, lingkungan belajar dipersiapan untuk memfasilitasi agar proses pembelajaran berpusat pada siswa (Aji \& Hudha, 2016).

\section{METODE PENELITIAN}

Penelitian ini menggunakan pendekatan kuantitatif. Data penelitian berupa angka-angka dan analisis menggunakan statistik, metode yang digunakan dalam penelitian ini adalah quasy experimen (eksperimen semu) dengan desain penelitian menggunakan Postest Only Group Design. Penelitian ini melibatkan dua kelas yaitu kelas eksperimen dan kelas kontrol yang diberi perlakuan berbeda. Kedua kelompok besar tersebut diberikan perlakuan dan selanjutnya akan diberikan posttest. Penelitian ini populasinya adalah siswa kelas VIII SMPN 10 Malang tahun ajaran 2018/2019 yang terdiri dari 8 kelas sejumlah 274 siswa. Teknik sampel dalam penelitian ini adalah Porpusive Sampling. Instrumen yang digunakan dalam penelitian ini adalah instrumen perlakuan berupa Silabus, Rencana Pelaksanaan Pembelajaran (RPP), dan Lembar Kerja Siswa (LKS). Sedangkan instrumen pengumpulan data yang digunakan yaitu posttest dan lembar observasi. Teknik analisis data yang digunakan adalah uji normalitas, uji homogenitas dan uji hipotesis. 
Tabel 1 Rancangan Eksperimen Postest Only Group Design

\begin{tabular}{lcc}
\hline Kelas & Perlakuan & Postest \\
\hline Eksperimen & $\mathrm{X} 1$ & $Q_{1}$ \\
\hline Kontrol & $\mathrm{X} 2$ & $Q_{2}$ \\
\hline
\end{tabular}

\section{HASIL DAN PEMBAHASAN}

Data penguasaan konsep IPA diperoleh melalui posttest menggunakan instrumen tes penguasaan konsep IPA yang dilaksanakan setelah siswa kelas eksperimen dan kelas kontrol mendapat perlakuan. Deskripsi data penguasaan konsep IPA siswa untuk kelas eksperimen sebanyak 30 siswa dan kelas kontrol sebanyak 30 siswa. Berdasarkan kegiatan pembelajaran yang menggunakan model Problem Based Leraning (PBL) memiliki nilai penguasaan konsep dengan nilai tertinggi 95 dan nilai terendah 60 sehingga memiliki nilai rata-rata sebesar 77,33. Sedangkan kegiatan pembelajaran yang menggunakan model konvesional memiliki nilai penguasaan konsep IPA dengan nilai tertinggi 90 dan terendah 60 sehingga memiliki nilai ratarata sebesar 71,66. Penilaian kerja ilmiah siswa dapat dianalisis berdasarkan peroleh skor dari hasil observasi kerja ilmiah siswa selama proses pemberian perlakuan. Kerja ilmiah siswa dinilai dengan rubrik penskoran kerja ilmiah siswa yang mempunyai skala 0-3. Berdasarkan nilai yang didapat kelas eksperimen yang menggunakan model Problem Based Learning (PBL) memiliki nilai kemampuan kerja ilmiah siswa dengan nilai tertinggi 95 dan nilai terendah 60 sehingga memiliki nilai rata-rata sebesar 75,83. Sedangkan kelas kontrol yang menggunakan model konvesional memiliki nilai kerja ilmiah siswa dengan nilai tertinggi 90 dan nilai terendah 55 sehingga memiliki nilai rata-rata sebesar 69,83 .

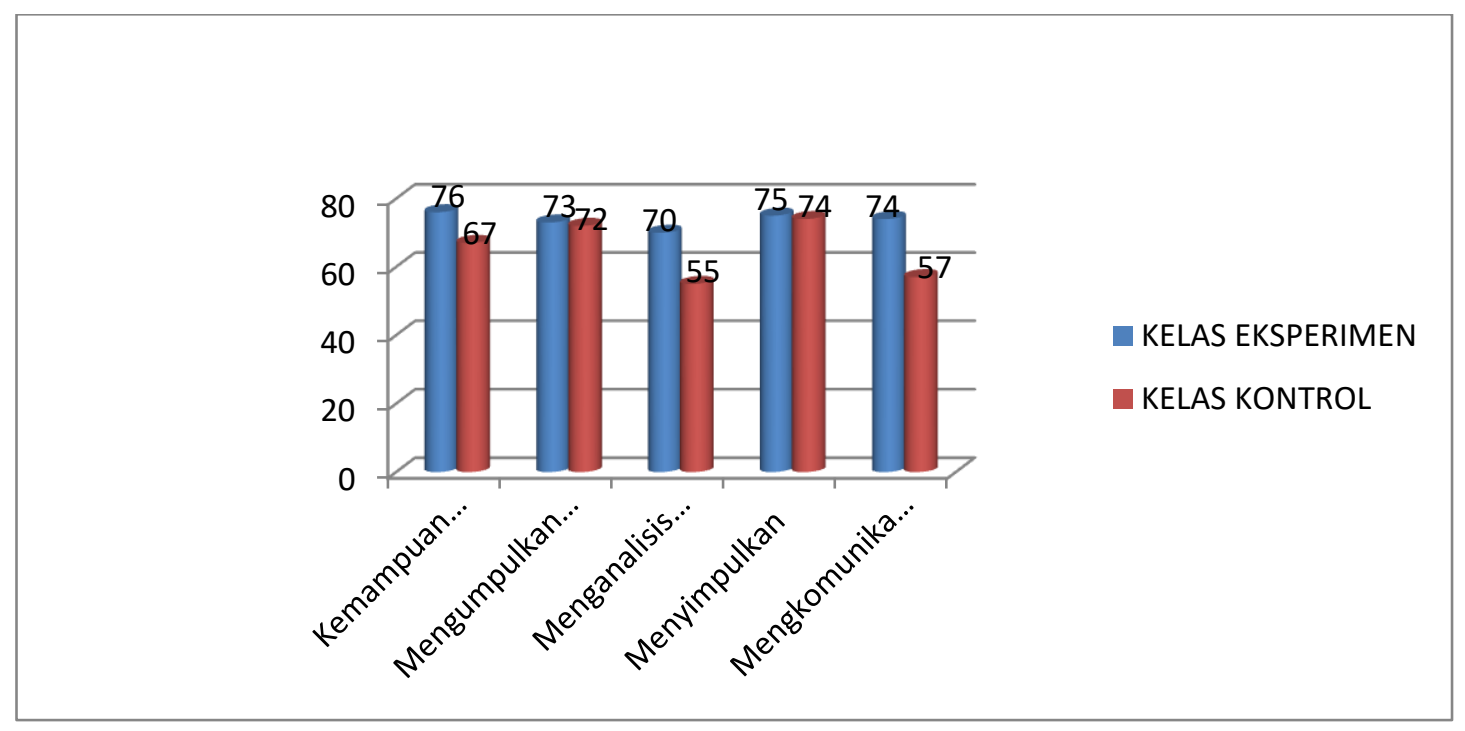

\section{Grafik 1 Rata-Rata Setiap Indikator atau Dimensi Kerja Ilmiah antara Kelas Eksperimen dan Kelas Kontrol}

Grafik 1. menunjukkan rata-rata setiap indikator atau dimensi kerja ilmiah antara kelas eksperime dan kelas kontrol terdapat perbedaan. Nilai rata-rata tertinggi setiap indikator didominasi oleh kelas eksperimen. Nilai yang diperoleh kelas eksperimen disetiap indikator sebesar 76,73,70,75,74. Nilai setiap indikator yang diperoleh kelas kontrol sebesar $67,72,55,74,57$. Dari nilai tersebut disimpulkan bahwa setiap indikator kerja ilmiah lebih tinggi dibandingkan dengan kelas kontrol. 
Hasil uji normalitas nilai penguasaan konsep IPA dengan taraf signifikansi 0,05. Berdasarkan hasil uji normalitas nilai penguasaan konsep IPA menunjukkan bahwa hasil uji normalitas penguasaan konsep IPA kelas eksperimen memiliki $\mathrm{L}_{\text {hitung }}<\mathrm{L}_{\text {tabel }}(0,06<0,16)$. Hasil uji normalitas kelas kontrol mempunyai $\mathrm{L}_{\text {hitung }}<\mathrm{L}_{\text {tabel }}(0,14<0,16)$. Sehingga dapat disimpulkan bahwa nilai penguasaan konsep IPA berdsarkan model pembelajaran terdistribusi normal. Hasil uji normalitas nilai kerja ilmiah siswa dengan taraf signifikansi 0,05. Berdasarkan hasil uji normalitas menunjukkan bahwa hasil kerja ilmiah siswa berdasarkan uji normalitas pada kelas eksperimen memiliki $\mathrm{L}_{\text {hitung }}<\mathrm{L}_{\text {tabel }}(0,12<0,16)$. Hasil uji normalitas kelas kontrol mempunyai $\mathrm{L}_{\text {hitung }}<\mathrm{L}_{\text {tabel }}(0,15<0,16)$. Sehingga dapat disimpulkan bahwa kerja ilmiah siswa terdistribusi normal.

Hasil uji homogenitas nilai penguasaan konsep IPA Dengan taraf signifikansi 0,05. Dari Hasil uji homogenitas menunjukkan bahwa nilai $\mathrm{X}^{2}{ }_{\text {hitung }}<\mathrm{X}_{\text {tabel }}{ }_{\text {ta }}(1,2851<75,624)$. Sehingga dapat disimpulkan bahwa nilai penguasaan konsep IPA berasal dari kelompok yang homogen. Hasil uji homogenitas nilai jerja ilmiah siswa disajikan pada Tabel 4.9 Dengan taraf signifikansi $\quad 0,05$. Berdasarkan Hasil uji homogenitas menunjukkan bahwa nilai $\quad \mathrm{X}^{2}{ }_{\text {hitung }}<$ $\mathrm{X}_{\text {tabel }}^{2}(1,2923<75,624)$. Sehingga dapat disimpulkan bahwa nilai kerja ilmiah berasal dari kelompok yang homogen.

Pengujian hipotesis dalam penelitian ini adalah (Independent Sampel T-Test) dengan bantuan microsoft exel 2010. Hipotesis diterima jika nilai $\mathrm{T}$ hitung lebih besar dari nilai $\mathrm{T}$ tabel $\left(\mathrm{T}_{\text {hitung }}>\right.$ dari $\left.\mathrm{T}_{\text {tabel }}\right)$ dan hipotesis ditolak jika nilai $\mathrm{T}$ hitung lebih kecil dari $\mathrm{T}$ tabel $\left(\mathrm{T}_{\text {hitung }}<\right.$ dari $\mathrm{T}_{\text {tabel }}$ ). Hasil uji hipotesis menggunakan uji independent sampel T-test dengan membandingkan nilai $\mathrm{T}$ tabel dan $\mathrm{T}$ hitung pada taraf signifikansi $5 \%(\alpha=0,05)$.

\section{Perbedaan Penguasaan Konsep Siswa yang Belajar Menggunakan Model Problem Based Learning (PBL)}

Berdasarkan data hasil analisis menunjukkan bahwa penguasaan konsep $\mathrm{T}_{\text {hitung }}>$ dari $\mathrm{T}_{\text {tabel }}(8,793>3,92)$. Hal ini berarti hasil uji statistika pada uji hipotesis menggunakan uji independent sampel T-test menunjukkan adanya perbedaan penguasaan konsep IPA yang belajar dengan menggunakan Problem Based Learning (PBL). Hasil analisis sesuai dengan pernyataan pada hipotesis pertama, yaitu ada perbedaan penguasaan konsep siswa yang belajar menggunakan model Problem Based Learning (PBL) dan siswa yang belajar menggunakan model konvesional. Hasil penelitian ini sesuai dengan penelitian (Rivo Panji Yudha, 2016) menunjukkan bahwa model PBL dalam proses pembelajaran dapat meningkatkan penguasaan konsep. Hasil kegiatan belajar pada kelas eksperimen menghasilkan pembelajaran yang lebih baik dibandingkan dengan kelas kontrol.

Kegiatan pembelajaran pada kelas eksperimen, pada tahap awal yaitu mengorientasikan siswa pada masalah dunia nyata. Selanjutnya guru menjelaskan kegiatan pembelajaran dengan menciptakan atau mendatangkan suatu masalah tentang seseorang yang berenang pada kedalaman tertentu yang berkaitan dengan topik pembelajaran dalam kehidupan sehari-hari, lalu meminta siswa untuk memecahkan masalah yang diberikan oleh guru tersebut. Kegiatan penyeledikan ini bertujuan membantu siswa mengembangkan kreativitas dalam memecahkan suatu permasalahan sehingga siswa dapat memahami dan menguasai konsep pada materi yang dipelajari (Widdy Sukma Nugraha, 2018).

Tahap kedua adalah mengorientasikan siswa, pada tahap ini guru akan membagi siswa kedalam beberapa kelompok dan membagi lembar kerja siswa yang akan digunakan selama 
melaksanakan kegiatan praktikum. Pada tahap pembelajaran ini serta melatih siswa untuk menyelesaikan masalah-masalah dan membantu siswa untuk lebih mudah dalam melaksanakan kegiatan praktikum dengan baik (Yuniati, 2011).

Tahap ketiga adalah membimbing penyelidikan individual maupun kelompok, pada tahap ini guru akan membimbing siswa melaksanakan praktikum tekanan zat cair dan diskusi untuk mengerjakan lembar kerja siswa. Selanjutnya guru akan menjelaskan kegiatan pembelajaran yang dilakukan siswa pada tahap pembelajaran ini yaitu meminta siswa melaksanakan praktikum, sesuai dengan prosedur yang tertera pada lembar kerja siswa serta mengolah data hasil praktikum. Model Problem Based Learning dapat membantu siswa untuk mampu menumbuhkan rasa ingin tahu siswa lebih dalam terhadap masalah yang dihadapi (Widdy Sukma Nugraha, 2018).

Tahap ke empat adalah mengembangkan dan menyajikan hasil karya, pada tahap ini guru meminta siswa untuk mempresentasikan hasil pemecahan masalahnya secara lisan. Selanjutnya guru akan menjelaskan kegiatan pembelajaran yang dilakukan siswa sehingga proses pembelajaran siswa lebih antusias dan apa yang telah dilakukan dan dipelajari akan tertanam kuat dalam ingatan (Suarsana et al., 2013).

Tahap akhir pembelajaran, guru membantu siswa melakukan evaluasi terhadap proses dan hasil penyelidikan yang telah dilakukan dengan memberi latihan soal. Pemberian latihan soal yang memberikan kesempatan kepada siswa untuk menyelesaikan masalah dengan sendiri tanpa meminta bantuan kepada teman. Kegiatan ini dapat membantu siswa dalam membiasakan diri bekerja mandiri dan siswa juga dapat mengetahui sejauhmana kemampuan yang telah mereka capai. Pemberian latihan soal akan membuat siswa mengetahui pemahamnnya terhadap konsep yang telah dipelajari (Yuselis et al., 2015)

Proses pembelajaran pada kelas kontrol adalah permasalahan yang disajikan pada tahap penyajian masalah sama dengan kelas eksperimen yaitu tentang seseorang yang berenang pada kedalaman tertentu. Ketika guru meminta perhatian siswa saat penyajian masalah, masih banyak siswa yang tidak memperhatikan guru karena sebagian dari siswa masih sibuk dengan kegiatannya masing-masing, selain itu ketika guru mengajukan pertanyaan berkaitan dengan masalah, hanya sedikit siswa yang menjawab karena masih sebagian besar siswa hanya diam dan tidak berpartisipasi dan menjawab pertayaan yang diajukan oleh guru. Proses pembelajaran menjadi kurang kondusif karena siswa merasa gelisah, bosan dan jenuh, sehingga siswa tidak dapat mengikuti pembelajaran dengan baik (Purwandari, Cholimah, \& Pradana, 2009).

Tahap pengorganisasian dan penyelidikan, siswa masih kesulitan saat melaksanakan praktikum dan mengolah data, karena ada penyajian LKS yang berbeda antara kelas kontrol dan kelas eksperimen, berbeda dengan kelas eksperimen pada kelas kontrol penyajian LKS tidak menyertakan poin fungsi alat dan bahan praktikum, hal ini menyebabkan masih banyak siswa yang kesulitan dalam menggunakan alat dan bahan praktikum,sehingga data praktikum kurang akurat. Kegiatan ini menyebabkan selama pembelajaran guru harus memberi bimbingan yang lebih itensif kepada siswa. Kegiatan analisis data, siswa juga masih sulit mengolah data hasil penyelidikan, hal tersebut terlihat dari jawaban siswa banyak yang kurang sesuai dengan hasil penyelidikan dan pemberian penjelasan yang kurang mendalam. Beberapa temuan penelitian pada kelas kontrol menjelaskan kesulitan siswa saat memahami dan menyelesaikan masalah, disebabkan karena kurang totalitas siswa dalam proes pembelajaran (Suarsana et al., 2013).

Model Problem-Based Learning (PBL) juga terlihat mendorong siswa untuk membaca materi dan berdiskusi untuk mencari jawaban dari permasalahan yang mereka dapatkan tanpa 
adanya penjelasan dari guru terlebih dahulu. Hal ini meningkatkan Penguasaan konsep siswa terhadap materi yang sedang dipelajarinya. Penguasaan konsep IPA penting bagi siswa untuk memperoleh dan mengombinasikan pengetahuan yang dimiliki. Selain itu, dapat membantu siswa dalam menyelesaikan suatu permasalahan yang ada dalam kejadian sehari-hari (Marlina, Utaya, \& Yuliati, 2017).

Pada model pembelajaran Problem-Based Learning (PBL), siswa memecahkan masalah secara berkelompok dalam investigasi kelompok dan mempresentasikan hasil dari pemecahan masalah tersebut. Langkah tersebut telah dapat membantu siswa menemukan pengetahuan sendiri untuk memhami materi. Hal ini sejalan dengan pendapat Trianto (dalam Purnamasari et al., 2016) bahwa kelebihan model pembejaran Problem Based Learning yaitu realistik dengan kemampuan siswa, konsep sesuai dengan kebutuhan siswa, memupuk sifat inkuirisiswa. Pada kelas kontrol berbeda dengan kelas eksperimen, dimana kelas ini masih menggunakan metode konvensional, dari awal guru memberikan materi siswa pada kelas kontrol terlihat bosan, kurang aktif dan hanya didominasi oleh beberapa siswa yang bertanya. Hal ini diperkirakan akibat aktivitas belajar hanya sebatas mendengarkan dan berdiskusi. Ini sesuai dengan pendapat (Purnamasari et al., 2016) "pembelajaran tidak bisa berjalan dengan baik apabila anak didik tidak membaca terlebih dahulu".

Berdasarkan data penelitian tentang pembelajaran antara kelas eksperimen dan kelas kontrol, dapat disimpulkan bahwa pembelajaran pada kelas eksperimen menghasilkan pembelajaran yang lebih baik. Model PBL ini sangat membantu siswa untuk meningkatkan penguasaan konsep IPA selama proses pembelajaran.

\section{Perbedaan Kerja Ilmiah Siswa Yang Belajar Dengan Model Problem-Based Learning (PBL)}

Berdasarkan data hasil analisis menunjukkan bahwa penguasaan konsep $\mathrm{T}_{\text {hitung }}>$ dari $\mathrm{T}_{\text {tabel }}(8,4656>3,92)$. Hal ini berarti hasil uji statistika pada uji hipotesis menggunakan uji independent sampel T-test menunjukkan adanya perbedaan kerja ilmiah siswa yang belajar dengan model Problem based Learning (PBL). Hasil analisis sesuai dengan pernyataan pada hipotesis kedua, yaitu ada perbedaan kerja ilmiah siswa dengan model Problem-Based Learning (PBL).

Perbedaan masing-masing indikator kerja ilmiah belajar dijelaskan sebagai berikut:

1. Kemampuan siswa dalam menggunaka alat dan bahan

Berdasarkan hasil analisis kelas eksperimen lebih antusias dalam menggunakan alat dan bahan serta mengetahui fungsi alat dan pengoperasian alat secara benar sedangkan dengan kelas kontrol guru yang lebih aktif dibandingkan siswa. Tidak semua siswa aktif dalam menggunakan alat dan bahan serta mengetahui fungsi alat dan pengoperasian alat secara benar. Contoh pada saat merangkai alat dan bahan pada saat praktikum kelas eksperimen lebih kompak pada saat merangkai alat. Pada kelas kontrol siswa kurang aktif dalam merangkai alat dan bahan praktikum. Hal ini menyebabkan kurangnya siswa merespon instruksi dari guru.

2. Mengumpulkan data

Berdasarkan data hasil penelitian, aspek melakukan mengumpulkan data pada kerja ilmiah nilai yang diperoleh kelas eksperimen lebih tinggi dibandingkan kelas kontrol. Dengan dibagikannya LKS memudahkan siswa untuk melaksanakan kegiatan praktikum sesuai dengan langkah yang terdapat pada LKS sesuai dengan hasil eksperimennya. Sedangkan kelas kontrol mendapatkan nilai yang lebih rendah karena dalam tahapan 
pembelajaran konvesional, guru lebih aktif dari pada siswa. Siswa yang nakal dan berkemampuan rendah akan cenderung diam dan bermain sehingga hanya beberapa siswa yang aktif dalam melaksanakan kegiatan praktikum. Tidak adanya pembagian tugas dalam kelompok sehingga siswa yang memiliki kemampuan yang lebih tinggi cenderung melakukan kegiatan praktikum sendiri sementara teman yang memiliki kemampuan yang rendah hanya menerima hasil. Tidak adanya kekompakan ini mengakibatkan lambatnya proses pengumpulan data. Contohnya kelas eksperimen pada saat praktikum berlangsung siswa sebagian besar siswa pada saat melakukan praktikum sangant berkosentrasi. Sehingga proses pengumpulan data tidak terjadi kesalahan. Berbeda dengan kelas kontrol sebagian besar dalam proses pengumpulan data tidak kompak dalam proses pengumpulan data.

3. Menganalisis data

Berdasarkan hasil analisis data, nilai kelas eksperimen lebih tinggi dari pada kelas kontrol. Hal ini dikarenakan kelas eksperimen dalam menjawab pertanyaan sesuai dengan hasil praktikum. Sedangkan kelas kontrol kurang antusias dalam mengerjakan. Hal ini mungkin dikarenakan metode dalam pembelajaran kurang bervariasi, tidak adanya diskusi bersama teman sejawat dalam menganalis data.

4. Menyimpulkan

Berdasarkan hasil analisis data, aspek menyimpulkan dalam kerja ilmiah kelas eksperimen mendapatkan nilai yang lebih tinggi dari pada kelas kontrol. Menarik kesimpulan akan memudahkan mereka akan secara jelas sesuai dengan hasil praktikumnya. Kelas kontrol akan mendapatkan nilai yang rendah karena dengan perlakuan pembelajaran konvesional yang disajikan guru sehingga siswa merasa kesulitan dalam menyimpulkan hasil parktikumnya.

5. Mengkomunikasikan hasil praktikum

Berdasarkan hasil data penelitian, aspek mengkomunikasikan atau mempresentasikan data dalam kerja ilmiah mendapatkan nilai yang lebih tinggi dari pada kelas kontrol. Hal ini dikarenakan segala yang didiskusikan sebelum mempresentasikan data dibahas berdasarkan keputusan bersama. penyusunan kata-kata dalam hal apapun yang akan disampaikan didiskusikan secara bersama. dengan pemantapan diskusi bersama ini membuat kelas eksperimen jauh lebih bagus. Sedangkan kelas kontrol karena kurangnya diskusi bersama dalam kelompok sehingga dalam mempresentasikan data hanya siwa yang memiliki kemampuan yang tinggi yang lebih aktif dari pada kemampuan yang lebih rendah.

Kerja ilmiah adalah suatu kegiatan untuk mendapatkan jawaban atas masalah atau pertanyaan yang menggunakan pendekatan keterampilan proses seperti keterampilan untuk mengamati, menanya, menafsirkan, meramal, mengelompokkan, menarik kesimpulan, dan mengkomunikasikan. Menurut Usman Samatowa (dalam Yuliana, Kresnadi, \& Utami, 2016) menyatakan, "Keterampilan Proses Sains merupakan keterampilan intelektual yang dimiliki dan digunakan oleh para ilmuan dalam meneliti fenomena alam". Indikator kerja ilmiah yang diukur dalam penelitian ini adalah kemampuan siswa dalam menggunaka alat dan bahan, mengumpulkan data, menganalisis data, menyimpulkan dan mengkomunikasikan hasil praktikum.

Siswa yang mempunyai kerja ilmiah cenderung mandiri dalam proses pembelajaran (Ratnaningtyas Martuti, Muhardjito Muhardjito, 2013). Dalam melaksanakan kegiatan 
penyelidikan atau praktikum, siswa yang mempunyai kerja ilmiah tinggi lebih mudah dalam memecahkan permasalahan yang diberikan oleh guru an mampu melaksanakan kegiatan praktikum secara sistematis, sedangkan siswa yang mempunyai kerja ilmiah rendah mereka terbantu dengan adanya LKS sehingga proses pemecahan masalah kurang terlaksana dengan baik sesuai yang diharapkan karena siswa tidak memiliki kreatifitas sendiri. Siswa yang mempunyai kemampuan kerja ilmiah kegiatan belajar dan unjuk kerjanya lebih terarah dan pengembangan konsepnya lebih luas. Dengan demikian, penelitian ini membuktikan bahwa adanya perbedaan kerja ilmiah antara siswa yang belajar dengan model Problem-Based Learning (PBL).

Hasil ini juga sejalan dengan hasil penelitian yang dilakukan oleh Veloo (2013) bahwa kerja ilmiah yang dimiliki siswa mampu mendorong mereka untuk lebih tertarik dan terlibat dalam pembelajaran IPA. Sementara siswa yang memiliki kerja ilmiah rendah cenderung tidak antusias dan sulit mengikuti proses pembelajaran sehingga sulit menguasai konsep pada materi tekanan zat cair. Untuk melatih kemampuan kerja ilmiah siswa berupa keterampilan mengamati, mengumpulkan informasi, menalar, menarik kesimpulan, dan mengkomunikasikan, seorang guru dapat memilih model pembelajaran yang sesuai dengan tujuan pembelajaran yang ditetapkan. Salah satu model yang dapat digunakan adalah Model Problem Based Learning.

Model Problem Based Learning merupakan pembelajaran menggunakan masalah dunia nyata sebagai suatu konteks bagi siswa untuk belajar tentang berpikir kritis dan keterampilan pemecahan masalah, serta untuk memperoleh pengetahuan dan konsep yang esensi dari mata pelajaran. Dalam hal ini siswa terlibat dalam penyelidikan untuk pemecahan masalah yang mengintegrasikan keterampilan dan konsep dari berbagai isi materi pelajaran. Berdasarkan pemaparan penjelasan disetiap aspek diatas dapat disimpulkan bahwa kerja ilmiah akan lebih mudah dikembangkan pada diri siswa jika dengan model pembelajaran yang sangat cocok diterapkan dalam kegiatan pembelajaran IPA.

\section{PENUTUP}

Berdasarkan hasil penelitian dan pembahasan tentang pengaruh model Problem Based Learning (PBL) terhadap penguasaan konsep dan kerja ilmiah pada materi IPA SMPN 10 malang, diperoleh kesimpulan sebagai berikut: Ada perbedaan penguasaan konsep siswa yang belajar dengan menggunakan Problem Based Learning (PBL), Ada perbedaan kerja ilmiah siswa yang belajar dengan model Problem-Based Learning (PBL).

\section{DAFTAR PUSTAKA}

Aji, S. D., \& Hudha, M. N. (2016). Kerja Ilmiah Siswa SMP dan SMA Melalui Authentic Problem Based Learning (APBL). Jurnal Inspirasi Pendidikan Universitas Kanjuruhan Malang, 6(1), 835-841.

Al-Fikry, I., Yusrizal, \& Syukri, M. (2018). Pengaruh Model Problem Based Learning Terhadap Kemampuan Berpikir Kritis Peserta Didik Pada Materi Kalor. Jurnal Pendidikan Sains Indonesia, 06(01), 17-23. https://doi.org/10.24815/jpsi.v6i1.10776

Anderson, L. W., \& Krathwohl, R. D. (2008). Psikologi Pendidikan. yogyakarta: Kencana Prenada Media Goup.

Firmansyah, R., Kosim, \& Ayub, S. (2015). Pengaruh Model Pembelajaran Berbasis Masalah Dengan Metode Eksperimen Pada Materi Cahaya Terhadap Hasil Belajar Fisika Siswa 
Kelas VIII SMPN 2 GUNUNGSARI TAHUN AJARAN 2014/2015. Jurnal Pendidikan Fisika Dan Teknologi, I(3), 154-159.

Gunantara, G., Suarjana, M., \& Riastini, N. P. (2014). Penerapan Model Pembelajaran Problem Based Learning Untuk Meningkatkan Kemampuan Pemecahan Masalah Matematika Siswa Kelas V. Jurnal Mimbar PGSD Universitas Pendidikan Ganesha 2(1).

Handayani, P., Agoestanto, A., \& Masrukan. (2013). Pengaruh Pembelajaran Berbasis Masalah Dengan Asesmen Kinerja Terhadap Kemampuan Pemecahan Masalah. Unnes Journal of Mathematics Education, 2(1).

Handika, I., \& Nur, W. M. (2013). Pengaruh Pembelajaran Berbasis Masalah Terhadap Penguasaan Konsep Dan Keterampilan Proses Sains Siswa Kelas V. Jurnal Prima Edukasia, I(1), 85-93.

Kono, R., \& Tangge, H. D. M. L. N. (2016). Pengaruh Model Problem Based Learning (Pbl) Terhadap Pemahaman Konsep Biologi Dan Keterampilan Berpikir Kritis Siswa Tentang Ekosistem Dan Lingkungan Di Kelas X SMA NEGERI 1 SIGI. Jurnal Sains Dan Teknologi Tadulako, 5(1), 28-38.

Marlina, Utaya, S., \& Yuliati, L. (2017). Pengaruh Authentic Problem Based Learning (aPBL) Terhadap Penguasaan Konsep IPA Siswa Kelas IV Sekolah Dasar, 2(11), 1509-1514.

Nadiya, I. (2017). Pengaruh Model Pembelajaran Problem Based Learning (PBL) Terhadap Penguasaan Konsep Siswa Pada Materi Sistem Saraf. Jurnal Pendidikan Biologi, 1-9.

Purnamasari, L., Zikra, \& Reza, F. (2016). Pengaruh Model Problem-Based Learning (PBL) Terhadap Penguasaan Konsep IPA Materi Pencemaran Lingkungan, II(2), 62-66.

Ratnaningtyas Martuti, Muhardjito Muhardjito, M. D. (2013). Pengaruh Pembelajaran Open Inquiry terhadap Prestasi Belajar Fisika ditinjau dari Kerja Ilmiah Siswa SMA Negeri 1 Blitar. Jurnal Pendidikan Sains.

Rivo Panji Yudha, M. P. (2016). Pengembangan Instrumen Asesmen Otentik Unjuk Kerja Materi Bangun Ruang Di Sekolah Dasar Kota Cirebon, 5(2).

Rusman. (2013). Model-model Pembelajaran (Mengembangkan Profesionalisme Guru). jakarta: PT Rajagrafindo Persada.

Siswono, H., Wartono, \& Supriyono, K. (2017). Pengaruh Problem Based Learning Berbantuan Kombinasi Real Dan Virtual Laboratory Terhadap Keterampilan Proses Sains Dan Penguasaan Konsep Siswa Di Sman 1 Lumajang. Jurnal Riset Pendidikan Fisika, 1(1), $3-10$.

Syafi'i, W., Suryawati, E., \& Saputra, A. R. (2011). Kemampuan Berpikir Kreatif Dan Penguasaan Konsep Siswa Melalui Model Problem Based Learning (PBL) Dalam Pembelajaran Biologi Kelas XI IPA SMAN 2 Pekanbaru Tahun Ajaran 2010/2011. Jurnal Biogenesis, 8(1).

Waldrip, B., Prain, V., \& Carolan, J. (2010). Using Multi-Modal Representations to Improve Learning in Junior Secondary Science. Research in Science Education 40:65-80, 65-80. https://doi.org/10.1007/s11165-009-9157-6

Yoesoef, A. (2015). Penerapan Model Problem Based Learning Untuk Meningkatkan Kemampuan Menanya Dan Penguasaan Konsep Fisika Kelas X MIA 1 SMA NEGERI 2 Kediri. Jurnal PINUS, 1(2).

Yuliana, Kresnadi, H., \& Utami, S. (2016). Pengaruh Model PBL Terhadap Kemampuan Kerja Ilmiah Siswa Pada Pembelajaran IPA DI SD. Jurnal Pendidikan Dan Pembelajaran, $5(10), 1-11$. 